\title{
Commentary: Doubling up on gene therapy for heart failure
}

\author{
Leora B. Balsam, MD
}

\footnotetext{
From the Division of Cardiac Surgery, University of Massachusetts School of Medicine, Worcester, Mass. Disclosures: Author has nothing to disclose with regard to commercial support.

Received for publication Sept 17, 2019; revisions received Sept 17, 2019; accepted for publication Sept 17, 2019; available ahead of print Oct 24, 2019.

Address for reprints: Leora B. Balsam, MD, Division of Cardiac Surgery, UMass Memorial Medical Center, University Campus, 55 Lake Ave N, Worcester, MA 01655 (E-mail: leora.balsam@umassmemorial.org).

J Thorac Cardiovasc Surg 2020;159:1820-1

$0022-5223 / \$ 36.00$

Copyright (C) 2019 Published by Elsevier Inc. on behalf of The American Association for Thoracic Surgery https://doi.org/10.1016/j.jtcvs.2019.09.044
}

Disruption of myocardial calcium homeostasis is a key feature of advanced heart failure. An important regulatory protein in this process is S100A1, an EF-hand calciumbinding and calcium-sensing protein located within the myocardial sarcoplasmic reticulum and contractile apparatus. ${ }^{1,2}$ In preclinical models, S100A1 has been identified as a positive inotropic regulator with actions that are independent of $\beta$-adrenergic signaling. ${ }^{1,3}$ Its positive effect on calcium handling occurs through downstream effectors, including SERCA2a, the calcium ion adenosine triphosphatase that transports calcium from the cytosol to the sarcoplasmic reticulum. In animal models of myocardial ischemia-reperfusion, myocardial infarction, and heart failure, S100A1 overexpression improves calcium handling, myocardial contractility, and cardiac function. ${ }^{3-7}$ S100A1 is a therefore a target of interest for human heart failure treatment.

In this issue of the Journal, Katz and colleagues ${ }^{8}$ report their evaluation of the efficacy of S100A1 gene therapy in a rat model of myocardial infarction. Adenoviral mediated S100A1 overexpression has been achieved previously ${ }^{3-6}$; however, some of the challenges in previous studies have been inefficient transduction of the target cells, transient effect as a result of short vector residence time in host cells, and off-target transduction in collateral organs. Advances in recombinant adenoviral vector design may improve transduction efficiency, and newer delivery techniques may limit collateral expression in off-target organs.

Katz and colleagues ${ }^{8}$ evaluated 2 different adenoassociated viral vector constructs in their model. One contained a capsid with single-stranded S100A1 DNA, and the other contained double-stranded S100A1 DNA. In theory, the double-stranded construct would avoid a ratelimiting DNA conversion step after entry in the target cell, which may improve its efficiency. Katz and colleagues ${ }^{8}$ delivered the virus through intramyocardial injection in the peri-infarct zone immediately after myocardial infarction and evaluated cardiac function, mitochondrial structure and function, and inflammatory response 10 weeks

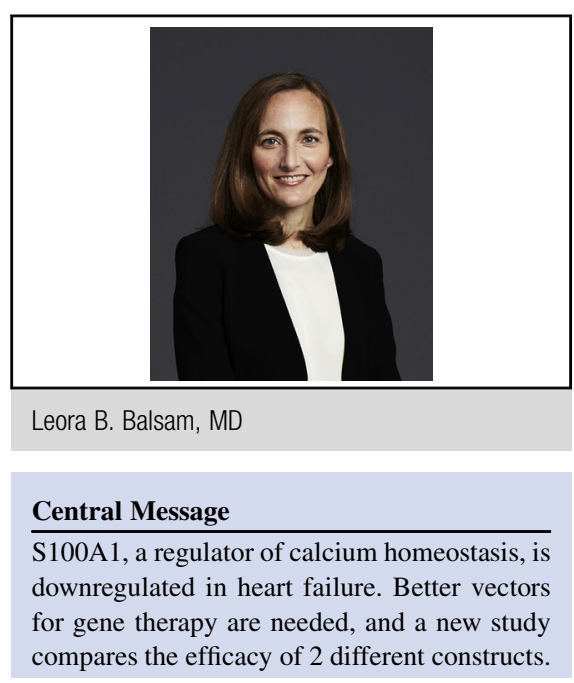

See Article page 1809 . later. They found a higher level of S100A1 expression with the double-stranded construct, a smaller infarct size relative to untreated controls, and improved cardiac function. At the mitochondrial level, both structure and function were better preserved with the double-stranded construct. Production of reactive oxygen species was lower in the double-stranded S100A1 construct treatment group than in the singlestranded group. Katz and colleagues ${ }^{8}$ conclude that gene therapy with double-stranded S100A1 vector has advantages relative to the single-stranded S100A1 vector, but that both can mitigate adverse postinfarct remodeling.

Translating preclinical gene therapy to the clinical realm remains a challenge. Although Katz and colleagues $^{8}$ have identified an S100A1 adeno-associated viral construct with efficient transduction, implementing it as a treatment tool for human disease is not straightforward. Factors that may limit the treatment efficacy include (1) natural immunity to the adeno-associated viral vector, (2) short-term residence of the viral vector within the target host cells, and (3) off-target infection of other host cells. Although preclinical large animal studies suggest that S100A1 overexpression does not have clear adverse consequences, ${ }^{5}$ the potential for harmful effects remains. Moreover, these investigators have previously shown that with the same double-stranded S100A1 construct, high levels of off-target transduction, which are in fact similar in magnitude to target cell transduction, occur in the liver. 6 
Recently, investigators reported negative results in the multicenter CUPID 2 (Calcium Upregulation by Percutaneous Administration of Gene Therapy in Cardiac Disease) trial, which targeted calcium handling in patients with advanced heart failure. ${ }^{9}$ Treatment with SERCA2a adenoassociated viral vector with an intracoronary method of delivery did not improve the clinical course of patients with heart failure with low ejection fraction. CUPID investigators concluded that the negative treatment effect may be related to an ineffective treatment dose. Similar obstacles would be faced with implementation of S100A1 gene therapy for patients with heart failure.

\section{References}

1. Most P, Bernotat J, Ehlermann P, Pleger ST, Reppel M, Borries M, et al. S100A1: a regulator of myocardial contractility. Proc Natl Acad Sci U S A. 2001;98: 13889-94.

2. Remppis A, Greten T, Schäfer BW, Hunziker P, Erne P, Katus HA, et al. Altered expression of the $\mathrm{Ca}^{2+}$-binding protein S100A1 in human cardiomyopathy. Biochim Biophys Acta. 1996;1313:253-7.
3. Most P, Pleger ST, Völkers M, Heidt B, Boerries M, Weichenhan D, et al. Cardiac adenoviral S100A1 gene delivery rescues failing myocardium. J Clin Invest. 2004 114:1550-63.

4. Pleger ST, Remppis A, Heidt B, Völkers M, Chuprun JK, Kuhn M, et al. S100A gene therapy preserves in vivo cardiac function after myocardial infarction. $\mathrm{Mol}$ Ther. 2005:12:1120-9.

5. Weber C, Neascu I, Krautz B, Schlegel P, Sauer S, Raake P, et al. Therapeutic safety of high myocardial expression levels of the molecular inotrope S100A1 in a preclinical heart failure model. Gene Ther. 2014;21: $131-8$.

6. Fargnoli AS, Katz MG, Williams RD, Kendle AP, Steurwald N, Bridges CR. Liquid jet delivery method featuring S100A1 gene therapy in the rodent model following acute myocardial infarction. Gene Ther 2016;23:151-7.

7. Jungi S, Fu X, Segiser A, Busch M, Most P, Fiedler M, et al. Enhanced cardiac S100A1 expression improves recovery from global ischemia-reperfusion injury. J Cardiovasc Transl Res. 2018;11:236-45.

8. Katz MG, Gubara SM, Hadas Y, Weber T, Kumar A, Eliyahu E, et al. Effects of genetic transfection on calcium cycling pathways mediated by double-stranded adeno-associated virus in postinfarction remodeling. J Thorac Cardiovasc Surg. 2020;159:1809-19.e3.

9. Greenberg B, Butler J, Felker M, Ponikowski P, Voors AA, Desai AS, et al. Calcium upregulation by percutaneous administration of gene therapy in patients with cardiac disease (CUPID 2): a randomized, multinational, double-blind, placebo controlled, phase 2b trial. Lancet. 2016;387:1178-86. 